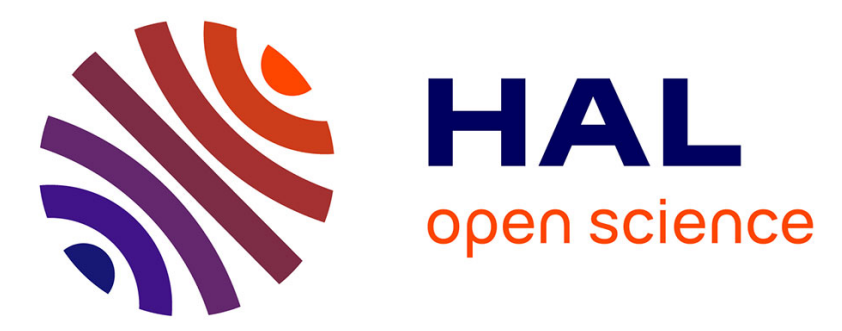

\title{
Contamination of ivory gulls (Pagophila eburnea) at four colonies in Svalbard in relation to their trophic behaviour
}

Magali Lucia, Hallvard Strom, Paco Bustamante, Dorte Herzke, Geir W. Gabrielsen

\section{To cite this version:}

Magali Lucia, Hallvard Strom, Paco Bustamante, Dorte Herzke, Geir W. Gabrielsen. Contamination of ivory gulls (Pagophila eburnea) at four colonies in Svalbard in relation to their trophic behaviour. Polar Biology, 2017, 40 (4), pp.917 - 929. 10.1007/s00300-016-2018-7 . hal-01662905

\section{HAL Id: hal-01662905 \\ https: / hal-univ-rochelle.archives-ouvertes.fr/hal-01662905}

Submitted on 28 Dec 2021

HAL is a multi-disciplinary open access archive for the deposit and dissemination of scientific research documents, whether they are published or not. The documents may come from teaching and research institutions in France or abroad, or from public or private research centers.
L'archive ouverte pluridisciplinaire HAL, est destinée au dépôt et à la diffusion de documents scientifiques de niveau recherche, publiés ou non, émanant des établissements d'enseignement et de recherche français ou étrangers, des laboratoires publics ou privés. 


\section{Contamination of four ivory gull (Pagophila eburnea) colonies in Svalbard in link with their trophic behaviour}

Magali Lucia $^{1 *}$, Hallvard Strøm ${ }^{1}$, Paco Bustamante ${ }^{2}$, Dorte Herzke ${ }^{3}$, Geir W. Gabrielsen ${ }^{1}$

${ }^{1}$ Norwegian Polar Institute, FRAM High North Research Centre for Climate and the Environment, 9296 Troms $\varnothing$, Norway

${ }^{2}$ Littoral, Environnement et Sociétés (LIENSs), UMR 7266 CNRS-Université de La Rochelle, 2 rue Olympe de Gouges, 17000 La Rochelle, France.

${ }^{3}$ Norwegian Institute for Air Research, FRAM High North Research Centre for Climate and the Environment, 9296 Troms $\varnothing$, Norway

*Corresponding author: Magali LUCIA

Email:m.lucia33@laposte.net

Address: Norwegian Polar Institute, Fram Centre

Hjalmar Johansens gt. 14

9296 Troms $\varnothing$, Norway

Telephone: (+47) 77750500

Fax: (+47) 77750501 
Abstract: The ivory gull (Pagophila eburnea) is a high-Arctic species considered endangered in most parts of its breeding range. Ivory gulls must cope with not only the reduction in sea ice cover triggered by climate change but also increasing contaminant loads due to changes in global contaminant pathways and the release of previously stored pollutants from melting snow and ice. This top predator may be affected by biomagnification processes of a variety of compounds with concentrations dramatically increasing from water to higher trophic levels. The objective of this study was therefore to assess the contaminant bioaccumulation of this species in four colonies located on Barentsøya, Svalbard, in link with its trophic behaviour. To that end, contaminants, including organochlorines (OCs), brominated flame retardants (BFRs), and perfluorinated alkyl substances (PFASs), were determined in the blood (plasma and whole blood) of ivory gulls sampled over several years. Carbon- and nitrogen-stable isotopes were also determined in different tissues (feathers, plasma and red blood cells, or whole blood) to infer the trophic level $\left(\delta^{15} \mathrm{~N}\right)$ and feeding habitat $\left(\delta^{13} \mathrm{C}\right)$ during both the breeding and moulting periods. The most quantitatively abundant contaminants found in the ivory gull were $p, p$ '-DDE (dichlorodiphenyldichloroethylene), RPCB (polychlorobiphenyl), and PFOS (perfluorooctane sulphonate). Several compounds including most of the PFASs, trans-nonachlor, cis-nonachlor, and BDE-28 were correlated with nitrogen values. This study highlighted variability in trophic behaviour among individuals during the breeding and the moulting periods. Overall, similar feeding habitats and strategies were used between breeding sites which was echoed by similar contaminant levels.

Keywords: Ivory gull, Perfluorinated alkyl substances, Persistent organic pollutants, Arctic, Isotopes 


\section{Introduction}

The Arctic region is currently undergoing dramatic environmental changes, with temperature increasing twice as fast as the global average and sea ice extent reaching a record minimum in 2012 with a reduction of $45 \%$ compared with the 1979-2010 climatology (Lei et al. 2015). It is predicted that climate change will result in profound modifications of the Arctic marine food web and contaminant pathways in this region. The main reasons involved are temperature increase, more low-pressure activity, increased river discharges and run-off from glaciers, and accelerated rate of sea ice melting (ACIA 2004; Hoegh-Guldberg and Bruno 2010). These climate-related variables may therefore influence the transport and thus the bioavailability of contaminants to Arctic biota (Macdonald et al. 2005).

The Arctic acts as a sink for contaminants produced in industrialized parts of the word and transported northward by air, sea, and water masses (de Wit et al. 2004). Amongst contaminants, persistent organic pollutants of anthropogenic origin have especially been found in Arctic biota for decades (Bourne and Bogan 1972; Gabrielsen et al. 1995). Recently, perfluorinated alkyl substances (PFASs) and brominated flame retardants (BFRs) also became widespread in the Arctic environment (Butt et al. 2010; de Wit et al. 2010). In particular, polybrominated diphenyl ethers (PBDE) constitute one of the main classes of brominated compounds used as flame-retardant additives that can be found in ecosystems and taxa (Renner 2000; Covaci et al. 2011). Due to their propensity for persistence and bioaccumulation in wildlife, PFASs and BFRs have become of global environmental concern in addition to legacy organochlorine (OC) compounds.

Among wild populations, seabirds are particularly vulnerable to contaminants because they are relatively long-lived species that bioaccumulate contaminants throughout their life. Moreover, most seabirds are predators that feed at the top of the food web (Hobson et al. 2002). They are thus affected by biomagnification processes of a variety of compounds (e.g. PFAS, polychlorinated biphenyl 'PCB') with concentrations dramatically increasing from water to higher trophic levels. Strong sub-lethal and/or lethal concentrations and adverse effects were observed at the individual (Dawson 2000) and population (Goutte et al. 2014a, b) levels. These adverse effects include endocrine disruption, impairment of the immune system, oxidative stress, or bone metabolism impairments (Verreault et al. 2004; Bourgeon et al. 2012; Pellerin Plourde et al. 2013).

In aquatic systems, food constitutes the major exposure route of seabirds to contaminants. One of the main goals in ecotoxicology is therefore to investigate more precisely the trophic ecology 
of species to better understand exposure pathways and explain contaminant concentrations in animal populations (Roscales et al. 2010; Leat et al. 2013). Stable isotopes of carbon and nitrogen are useful tools to examine trophic relationships and/or origins of prey to elucidate broad-scale, inter- and intraspecific dietary patterns, and so to determine whether differences in foraging strategies explain variations in contaminant uptake (Jardine et al. 2006). The basic isotopic concept is that an animal's chemical composition is directly influenced by what it consumes. Consumers are enriched in ${ }^{15} \mathrm{~N}$ relative to their food and consequently, stable nitrogen isotope measurements $\left(\delta^{15} \mathrm{~N}\right)$ serve as indicators of a consumer trophic position. By contrast, stable carbon ratios $\left(\delta^{13} \mathrm{C}\right)$ vary little along the food chain, and in the marine environment, $\delta^{13} \mathrm{C}$ values are mainly used to indicate the foraging habitats of predators (e.g. benthic versus pelagic habitats, inshore versus offshore; Hobson 1995).

The ivory gull (Pagophila eburnea) is a high-Arctic species that frequents ice-filled waters throughout the year. The main wintering grounds identified for northeast Atlantic populations (north Greenland, Svalbard and Franz Josef Land) of this long-distant migrant species are in south-east Greenland, along the Labrador sea ice edge and in the Bering Strait region (Gilg et al. 2010; Spencer et al. 2014). Adults have only a single moult per cycle, a strategy unique among gulls (Howell 2001). Their prebasic moult starts in March and April and is mostly completed before the pre-laying to hatching period (mid-June to early August). The primary moult is then suspended at this time, and the moult of outermost primaries is concluded in late August or September. Consequently, moulting and breeding greatly overlap in the ivory gull, presumably an adaptation to the constraints of its high-latitude winter range and the brief Arctic summer (Howell 2001). The ivory gull is considered endangered in most parts of its breeding range, especially in Canada, where studies documented an $80 \%$ decline in numbers since the 1980s (Gilchrist and Mallory 2005). Nevertheless, it is one of the world's most poorly known seabird species even though its high position in the marine food web makes it particularly sensitive to contaminant exposure (Karnovsky et al. 2009). Previous studies demonstrated that this free-ranging Arctic species is exposed to high contaminant concentrations along its distribution range in the Canadian, Norwegian, and Russian Arctic (Braune et al. 2007; Miljeteig et al. 2009; Lucia et al. 2015). It is thought that some ivory gulls specialize on scavenging remains of polar bear kills, whereas others feed mainly on polar cod (Boreogadus saida) and crustaceans associated with the ice edge (Divoky 1976; Mehlum 1990; Mehlum and Gabrielsen 1993; Karnovsky et al. 2009). Overall, climate-related perturbations (e.g. reduction in sea ice cover, modification of the Arctic marine food web, modification of pollutant 
bioavailability) are expected to profoundly impact the trophic behaviour of the ivory gull and potentially increase its contaminant exposure.

Consequently, the aim of this study was to better understand the contaminant exposure and foraging strategies of the ivory gull considering the lack of data for this vulnerable seabird. Our objective was to describe contaminant exposure and trophic behaviour of four ivory gull colonies located on Barentsøya, Svalbard, to finally investigate their relationship. Contaminants, encompassing a number of OCs, BFRs, and PFASs, were determined in the blood (plasma and whole blood) of ivory gulls sampled over 4 years. Carbon- and nitrogenstable isotopes were also determined in different tissues, including feathers and blood (plasma and red blood cells, or whole blood depending on the year) to investigate the foraging ecology during both the breeding and the moulting periods. The stable isotope method is based on timeintegrated assimilated food. Hence, the isotopic value of blood and feathers is representative of the isotopic niche of seabirds during the weeks preceding sampling and the moulting period, respectively.

\section{Materials and methods}

\section{Sample collection and preparation}

Ivory gulls were sampled for blood and ventral feathers between 2011 and 2014 in four breeding colonies (Auga, Freemanbreen, Hübnerbreen, Sigden, Fig. 1) on Barentsøya, Svalbard, and along the ice edge in Spring (April). When possible, both tissues were sampled on each bird (53\% of the samples). Moreover, different individuals were sampled among years. Birds were caught by the use of a single-catch closing net trap (spring trap) baited with a small piece of seal blubber. When it was possible, age and sex were determined, as well as morphometric measurements (e.g. mass, bill length, bill height, head-bill, wing length). Overall, whole blood was sampled for isotope analyses in $2011(n=6), 2012(n=5)$ and $2013(n=9)$, whereas plasma and red blood cells (erythrocytes) were obtained after centrifugation in the field (4000 rpm, 10 $\min )$ in $2013(\mathrm{n}=38)$ and $2014(\mathrm{n}=38)$. Ventral feathers were sampled in $2011(\mathrm{n}=19), 2012$ ( $\mathrm{n}=40), 2013(\mathrm{n}=46)$, and $2014(\mathrm{n}=34)$. Over the years, plasma and red blood cells were sampled in four colonies: Auga $(n=5)$, Freemanbreen $(n=27)$, Hübnerbreen $(n=19)$, and Sigden $(n=25)$, whereas whole blood was sampled in three colonies: Auga $(n=1)$, Freemanbreen $(n=8)$, and Hübnerbreen $(n=5)$, and the ice edge $(n=6)$, and feathers, in four colonies, Auga $(n=5)$, Freemanbreen $(n=71)$, Hübnerbreen $(n=30)$, Sigden $(n=25)$, and the ice edge $(n=8)$. 
Of those samples, blood volumes were sufficient to analyse contaminants such as PFASs in plasma samples in $2013(\mathrm{n}=38)$ and $2014(\mathrm{n}=21)$, and whole blood in $2011(\mathrm{n}=4), 2012(\mathrm{n}$ =5) and $2013(\mathrm{n}=1)$. Organochlorines and BFRs were analysed on fewer samples due to the higher volume required for the extraction protocol. Therefore, plasma samples were available in $2013(n=30)$ and $2014(n=9)$, and whole blood in $2011(n=4)$ and $2012(n=2)$. Over the years, PFASs were analysed in plasma samples from Auga $(n=5)$, Freemanbreen $(n=26)$, Hübnerbreen $(\mathrm{n}=18)$, and Sigden $(\mathrm{n}=10)$, and in whole blood samples from Auga $(\mathrm{n}=1)$, Freemanbreen $(n=5)$, and on the ice edge $(n=4)$.

Organochlorines and BFRs were analysed in plasma samples from Auga $(n=2)$, Freemanbreen $(\mathrm{n}=17)$, Hübnerbreen $(\mathrm{n}=13)$, and Sigden $(\mathrm{n}=7)$, and in whole blood samples from Freemanbreen $(n=2)$ and along the ice edge $(n=4)$. This difference in sampling method (whole blood versus plasma) is explained by the late capacity to centrifuge blood on a remote fieldwork on Barentsøya. Both tissues are useful for studying different contaminants. The use of whole blood has been recommended when analysing OCs and BFRs to avoid loss of contaminants present in the cellular fraction (Volz et al. 2001; Leslie et al. 2007). Serum or plasma can be used for analysis of many contaminants but it is notable that concentrations of some poly- and perfluoroalkyl substances (PFASs) in whole blood are approximately half those in serum or plasma because of the volume displacement of cellular components, which do not appear to function as a sorbent for these substances (Ehresman et al. 2007). All the blood samples, including plasmas and red blood cells, were kept frozen at $-20{ }^{\circ} \mathrm{C}$ until further analyses. Ventral feathers were washed to remove oil and dirt in a chloroform-methanol solution (2:1) in an ultrasonic bath for $2 \mathrm{~min}$. Afterward, they were rinsed in two consecutive pure methanol baths for a few seconds and dried at $40{ }^{\circ} \mathrm{C}$ for $48 \mathrm{~h}$.

\section{Nitrogen and carbon stable isotope analysis}

Depending on birds and years, stable isotopes were determined in ventral feathers and either on the whole blood or on the plasma and red blood cells (see above). Analyses were performed at the UMR 7266 CNRS-Université de La Rochelle in France. Cleaned feathers of ivory gulls were chopped using surgical stainless-steel scissors and accurately weighed $( \pm 0.001 \mathrm{mg})$ to a range between 0.1 and $0.4 \mathrm{mg}$. Blood samples were freeze-dried, grounded, and then weighed with the same accuracy and in the same range of masses. All samples were placed in tin capsules for carbon- and nitrogen-stable isotope analysis and analysed using an elemental analyser (Flash EA 1112 fitted with a "Zero Blank” option, Thermo Scientific, Milan, Italy) coupled to an 
isotope ratio mass spectrometer (Delta V Advantage, Conflo IV interface, Smart EA option, Thermo Scientific, Bremen, Germany). The results are reported in $\delta$ unit notation (expressed in per mil relative to standards: Vienna Pee Dee Belemnite for $\delta^{13} \mathrm{C}$ and $\mathrm{N}_{2}$ in air for $\delta^{15} \mathrm{~N}$ ). Withinrun replicates of internal standards (acetanilide) were run, and values were on average $-27 \pm$ $0.03 \%$ and $1 \pm 0.05 \%$ for $\delta^{13} \mathrm{C}$ and $\delta^{15} \mathrm{~N}$, respectively.

\section{Determination of OCs and BFRs}

OCs and BFRs were analysed from the plasma of 32 birds in 2013 and 9 birds in 2014. The whole blood of 4 birds in 2011 and 2 birds in 2012 was also analysed. Analyses were performed at the Norwegian Institute for Air Research (NILU) in Troms $\varnothing$. Organochlorine pesticides ( $o, p$ ' DDT, $p, p^{\prime} \mathrm{DDT}, o, p^{\prime} \mathrm{DDE}, p, p^{\prime} \mathrm{DDE}, o, p^{\prime} \mathrm{DDD}, p, p^{\prime} \mathrm{DDD}, \mathrm{HCB}$, trans-, cis-chlordane, oxychlordane, trans-, cis-nonachlor and mirex) and 12 PCB congeners (PCB-28, -52, -99, -101, $-105,-118,-138,-153,-180,-183,-187$ and -194) were searched for. BFRs encompassed 8 PBDE congeners (BDE-28, -47, -99, -100, -138, -153, -154 and -183), BATE (2-Bromoallyl2,4,6-tribromophenyl ether), TBPA (Tetrabromophthalic Anhydride), PBT (Pentabromotoluene), PBEB (Pentabromoethylbenzene), DPTE (2,3-Dibromopropyl- 2,4,6tribromophenyl ether), HBB (Hexabromobenzene), BTBPE (1,2-Bis (2,4,6-tribromophenoxy) ethane), BEHTBP (Bis (2-ethylhexyl) tetrabromophthalate), EHTeBB (2-Ethylhexyl- 2,3,4,5tetrabromobenzoate). Internal standard solutions $\left({ }^{13} \mathrm{C}\right.$-labelled compounds from Cambridge Isotope Laboratories: Woburn, MA, USA) were added to a blood sample of $0.7-1.5 \mathrm{ml}$. The sample was extracted twice with $6 \mathrm{ml}$ of $\mathrm{n}$-hexane, after denaturation with ethanol and a saturated solution of ammonium sulphate in water. Matrix removal on florisil columns, separation on an Agilent Technology 7890 GC (gas chromatography) and detection on an Agilent Technology 5975C MSD (mass spectrometry) were performed as described by Herzke et al. (2009). The limit of detection (LoD) was threefold the signal-to-noise ratio for the analysed BFRs and OCs and ranged between 0.6 and 14,596 $\mathrm{pg} \mathrm{g}^{-1}$ wet weight (wet wt) for HCB and TBPA, respectively. For validation of the results, blanks (clean and empty glass tubes treated like a sample) were run for every 10 samples, while standard reference material (1589a human serum from NIST) was also run for every 10 samples. Blank samples were below the detection limit for most reported analytes, and results from samples were deemed acceptable. 


\section{Determination of PFASs}

Twenty PFASs were analysed at NILU, encompassing 6:2 FTS, 8:2 FTS, PFBS (perfluorobutane sulphonate), PFHxS (perfluorohexane sulphonate), PFHpS (perfluoroheptane sulphonate), PFOS (perfluorooctane sulphonate), PFDcS (perfluorodecane sulphonate), PFOSA (perfluorooctane sulphonamide), PFBA (perfluorobutanoate), PFPeA (perfluoropentanoate), PFHxA (perfluorohexanoate), PFHpA (perfluoroheptanoate), PFOA (perfluorooctanoate), PFNA (perfluorononanoate), PFDA (perfluorodecanoate), PFUnDA (perfluoroundecanoate), PFDoDA (perfluorododecanoate), PFTriA (perfluorotridecanoate), PFTeA (perfluorotetradecanoate), and PFHxDA (perfluorohexadecanoate).

Prior to analysis, samples were extracted and prepared as described previously (Powley et al. 2005). A sample volume of $0.2 \mathrm{~mL}$ of plasma or whole blood was spiked with $20 \mu \mathrm{L}$ of the internal standard, a ${ }^{13} \mathrm{C}$ perfluorinated compound mix, and subsequently extracted with $1 \mathrm{~mL}$ methanol in three consecutive 10 min ultrasonic treatments.

After centrifugation, $0.8 \mathrm{~mL}$ of the supernatant solution was added to $25 \mathrm{mg}$ ENVI-Carb and $50 \mu \mathrm{L}$ glacial acetic acid and vortexed thoroughly. After additional centrifugation at 10,000 rpm for $10 \mathrm{~min}, 0.5 \mathrm{~mL}$ of the solution was transferred to a vial and $2040 \mathrm{pg}$ of 3,7-br-PFDA as a recovery standard was added. Prior to measurement, $50 \mu \mathrm{L}$ of a $2 \mathrm{mM}$ aqueous ammonium acetate solution was added to the same volume of samples.

All standards were purchased as crystalline substances from Wellington with purities greater than $95 \%$. Instrumental measurement was carried out according to Hanssen et al. (2013).

Recoveries of the mass-labelled internal standards were $89 \pm 12 \%$ for ${ }^{13} \mathrm{C} \mathrm{PFHxS}, 87 \pm 14 \%$ for ${ }^{13} \mathrm{C}$ PFOS, $96 \pm 11 \%$ for ${ }^{13} \mathrm{C}$ PFOA, $113 \pm 31 \%$ for ${ }^{13} \mathrm{C}$ PFNA, $104 \pm 14 \%$ for ${ }^{13} \mathrm{C}$ PFDA, $108 \pm 14 \%$ for ${ }^{13} \mathrm{C}$ PFUnDA, $126 \pm 22 \%$ for ${ }^{13} \mathrm{C}$ PFDoDA, and $136 \pm 29 \%$ for ${ }^{13} \mathrm{C}$ PFTeA

\section{Data treatment and statistical analyses}

Several compounds that were detected or analysed in less than $60 \%$ of the samples were excluded from statistical analyses including $o, p$ ' DDT, $p, p^{\prime}$ DDT, $o, p$ ' DDE, $o, p$ ' DDD, $p, p$ ' DDD, cis-chlordane, PCB-152, BDE-138, BATE, TBPA, PBT, PBEB, DPTE, BTBPE, BEHTBP, EHTeBB, 6:2 FTS, 8:2 FTS, PFBS, PFHpS, PFDcS, PFOSA, PFBA, PFPeA, PFHxA, PFHpA, PFOA, PFHxDA. Values below the quantification limit were taken into account in calculation of the means by assigning them values one-half of the detection limit for the given contaminant (e.g. a value $<0.02$ was reported as $0.01 \mathrm{ng} \mathrm{g}^{-1}$ wet wt). Contaminant concentrations are expressed in $\mathrm{ng} \mathrm{g}^{-1}$ wet wt. 
As normality and homogeneity of variance were not achieved despite $\log _{10}(x+1)$ transformation (Cochran C test), non-parametric analysis of variance (Kruskal-Wallis and Mann-Whitney Utest) was applied to assess differences in contaminant concentrations and stable isotope signatures for each parameters (colony, year, sex). Moreover, the Spearman test was applied to study correlations between parameters (contaminant concentrations and stable isotope values).

\section{Results}

\section{Isotopic values depending on the colony, year, and sex of birds}

Trophic positions and foraging habitats, assessed respectively through the determination of $\delta^{15} \mathrm{~N}$ and $\delta^{13} \mathrm{C}$, of the ivory gull were investigated in the feathers, whole blood, plasma and red blood cells (Fig. 2). Figure 2 shows the mean isotopic values of the tissues studied. Individual variability was observed for each tissue. Stable carbon isotope values of feathers were especially variable, ranging between -20.8 and $-17.5 \%$. Stable nitrogen isotope values in the plasma also ranged widely, varying between 13.0 and $16.3 \%$.

Stable isotope values were compared between colonies to identify any diverging trends in trophic behaviour between birds breeding on Barentsøya. Birds from the Sigden colony showed significant differences in their stable isotope values compared to birds coming from other colonies. Figure 3 presents red blood cell mean values for all colonies, all years consolidated. Birds sampled at Sigden displayed significantly lower $\delta^{13} \mathrm{C}$ values than birds from Freemanbreen and Hübnerbreen colonies, as well as lower $\delta^{15} \mathrm{~N}$ values than individuals from Hübnerbreen $\left(\delta^{13} \mathrm{C}\right.$ : Sigden vs Freemanbreen $\mathrm{p}=0.005$, Sigden vs Hübnerbreen $\mathrm{p}<0.0001$; $\delta^{15} \mathrm{~N}$ : Sigden vs Hübnerbreen $\mathrm{p}=0.043$ ). However, birds coming from Sigden were only sampled in 2014. To exclude year as confounding factor, stable isotope values were compared between colonies sampled in 2014 only. However, only Freemanbreen and Sigden could be compared because of low number of birds sampled in other colonies. The same trend was consequently observed that year. Sigden birds displayed lower stable isotope values than birds from Freemanbreen $\left(\delta^{13} \mathrm{C}: \mathrm{p}=0.024 ; \delta^{15} \mathrm{~N}: \mathrm{p}=0.031\right)$. Furthermore, plasma $\delta^{13} \mathrm{C}$ values were also significantly different between both colonies in 2014 (Sigden: -21.3 $\pm 0.1 \%$, Freemanbreen: $-21.7 \pm 0.1 \% ; p=0.038$ ). Similarly, sex could be considered as a confounding factor that may be responsible for differences observed between colonies. Unfortunately, it was not possible to sex all individuals used to study differences between colonies, especially in 2014. All the birds from Sigden were sampled that year, and only 7 individuals were sexed (F $=4, \mathrm{M}=3$ ). However, when available, the number of males and females was balanced between 
colonies. For example, in 2013, numbers between males and females, if not equal, were in the same range (Freemanbreen: $M=12, F=5$; Auga: $M=1, F=2$; Hübnerbreen: $M=10, F=6$ ). Consequently, the sex of birds was most likely not responsible for differences observed between colonies. For whole blood, differences appeared between birds sampled on the ice edge and those from Freemanbreen. Ivory gulls from the ice edge had significantly lower $\delta^{15} \mathrm{~N}$ values $(14.2 \pm 0.3 \%)$ than those from Freemanbreen $(14.9 \pm 0.2 \%)$, Kruskal-Wallis test, $p=0.045)$. However, birds from the ice edge and Freemanbreen were sampled on different years, 2011 and 2012-2013, respectively. It is therefore difficult to know whether this discrepancy is rather due to the year instead of the sampling location. In addition, feather values were similar between colonies for $\delta^{15} \mathrm{~N}$ and $\delta^{13} \mathrm{C}$.

The difference in stable isotope values between sampling years was investigated in feathers, plasma and red blood cells. The influence of year was not studied in whole blood because of the few available samples for this tissue. Overall, no differences were observed for feathers and plasma. Conversely, $\delta^{13} \mathrm{C}$ values in red blood cells were significantly higher in 2013 (-20.6 \pm $0.1 \%$ ) compared to $2014(-21.0 \pm 0.1 \%$; $p<0.0001$, Mann-Whitney U test $)$.

Finally, the influence of sex on stable isotope values was investigated. The only significant difference was between $\delta^{13} \mathrm{C}$ values of male $(-20.6 \pm 0.04 \%, \mathrm{n}=29)$ and females $(-20.8 \pm 0.07$ $\%, \mathrm{n}=16)$ in red blood cells $(\mathrm{p}=0.044$, Mann-Whitney $U$ test $)$.

\section{Influence of the time, location, and sex on contaminant concentrations}

Mean concentrations of PFASs, OCs and BFRs in plasma and whole blood of ivory gulls are presented in Tables 1 and 2 for each sampling year. Firstly, the influence of time, therefore year, was investigated independently of colonies for each tissue. For PFASs, no significant differences were observed between sampling years for both tissues (Table 1). Plasma concentrations of BDE-100 and BDE-154 were, however, significantly higher in 2013 compared to 2014 (BDE-100: $\mathrm{p}=0.002$, BDE-154: $\mathrm{p}=0.044)$, whereas whole blood concentrations were similar between years.

The influence of sampling location (colony) was consequently investigated, independently of the year and the sex of individuals. In plasma, discrepancies appeared for PFASs. Gulls captured at Auga displayed significantly lower PFOS, PFUnDA and PFDoDA concentrations than birds from Freemanbreen (PFOS: $14.9 \pm 1.2$ and $35.8 \pm 4.0$, PFUnDA: $7.2 \pm 0.9$ and 14.4 \pm 1.3, PFDoDA: $1.33 \pm 0.16$ and $2.66 \pm 0.24 \mathrm{ng} \mathrm{g}^{-1}$ wet wt for Auga and Freemanbreen, respectively; $\mathrm{p}<0.05$, Kruskal- Wallis test). To exclude sex as confounding factor, PFAS concentrations were compared on females only. Similar differences occurred between Auga 
and Freemanbreen for PFOS, PFUnDA, and PFDoDA ( $\mathrm{p}<0.05)$. Unfortunately, not enough samples were available in Auga to test for year as confounding factor. Organochlorine and BFR concentrations were not different between colonies for all the tissues studied.

Because of the potential maternal transfer of contaminants to eggs, sex-dependent differences in contaminant concentrations were also examined. The influence of this parameter appeared important for PFAS accumulation. Plasmatic concentrations of males $(n=28)$ were higher for all PFASs than females $(n=15)$, with the exception of PFNA and PFHxS $(\mathrm{p}<0.05$, MannWhitney $\mathrm{U}$ test). In contrast, males $(\mathrm{n}=22)$ displayed lower HCB concentrations in the plasma than females $\left(n=11 ; 7.19 \pm 0.75\right.$ vs $9.62 \pm 0.39 \mathrm{ng} \mathrm{g}^{-1}$ wet wt; $\mathrm{p}=0.012$, Mann-Whitney $\mathrm{U}$ test).

The relationship between contaminants and body mass of birds was investigated. Plasma concentrations of PFASs were positively correlated with the body mass of birds ( $\mathrm{r}$ ranged between 0.27 for PFHxS and 0.51 for PFDA). Simultaneously, HCB, PCB-118, and BDE-99 plasma concentrations were negatively correlated with the body mass of ivory gulls $(r=-0.42$, -0.32 and -0.48 , respectively; Spearman test, $\mathrm{p}<0.05)$.

\section{Relationship between trophic position, feeding habitat and contaminant bioaccumulation}

All colonies and years combined, PFAS concentrations were significantly correlated with d15N values in the plasma ( $\mathrm{r}$ comprised between 0.37 for PFOS and 0.52 for PFTeA; $\mathrm{p}<0.05$, Spearman test). Only PFHxS and PFNA concentrations were not significantly correlated with stable nitrogen isotope values. In contrast, $\delta^{13} \mathrm{C}$ values were not correlated with PFAS concentrations. The same trend was observed in whole blood. No correlations were observed between PFAS concentrations and $\delta^{13} \mathrm{C}$ values, whereas $\delta^{15} \mathrm{~N}$ values were significantly correlated with most of the PFASs, with the exception of PFHxS and PFNA ( $r$ comprised between 0.66 for PFUnDA and 0.80 for PFTriA; $p<0.05$, Spearman test).

For OCs and BFRs, $\delta^{15} \mathrm{~N}$ values in plasma samples were positively correlated with transnonachlor $(\mathrm{r}=0.41)$, cisnonachlor $(\mathrm{r}=0.32)$, and BDE-28 $(\mathrm{r}=0.78)$, whereas $\delta^{13} \mathrm{C}$ values were only correlated with trans-nonachlor $(r=0.35$; Fig. 4$)$.

\section{Discussion}

We investigated the contaminant bioaccumulation in one of the most poorly researched seabirds in the Northern hemisphere, the ivory gull, and the relationship with its trophic habits. The trophic diet of this species has been previously described in Svalbard (Mehlum and Gabrielsen 
1993) and other Arctic areas such as the Barents Sea (Mehlum 1990), the Chukchi Sea (Divoky 1976), and in northern Baffin Bay (Karnovsky et al. 2009). However, the large sample size of two non-invasive measures of long-term diet (e.g. blood and feathers) in our study provides an excellent opportunity to examine the relationship between contaminants and trophic ecology of ivory gulls, over several years and sampling locations on Barentsøya, Svalbard.

\section{Contaminant bioaccumulation in the ivory gull}

Results in this study are similar to previously reported results in ivory gull eggs where high concentrations were reached for OCs, especially $p, p$ '-DDE and PCBs (Braune et al. 2007; Miljeteig et al. 2009; Lucia et al. 2015). Previous experimental studies in birds have demonstrated that exposure to various OCs, such as PCB, DDE and mirex, affect parental behaviour. This has often been attributed to endocrine disruption or neurological disorders (McArthur et al. 1983; Peakall 1985; Keith and Mitchell 1993). Bustnes et al. (2001) demonstrated that plasma PCB concentrations in glaucous gulls (Larus hyperboreus) nesting on Bjørnøya, Svalbard, were positively correlated with the proportion of time birds were absent from the nest with concentrations ranging from 52 to $1079 \mathrm{ng} \mathrm{g}^{-1}$ wet wt. This study included eight PCB congeners. With 11 congeners in the present study, concentrations ranged between 134 and $1597 \mathrm{ng} \mathrm{g}^{-1}$ wet wt, which could imply potential reproductive disruptions for the ivory gull.

Perfluorinated organic compounds have been reported in tissues of Arctic biota (Butt et al. 2010). The most predominant PFAS in this study was PFOS. This result was similar to previous reports for Canadian (Martin et al. 2004; Tomy et al. 2004) and Norwegian Arctic avian wildlife (Verreault et al. 2005; Lucia et al. 2015). Levels observed in plasma samples of ivory gulls were below or of the same order of magnitude than those reported for the glaucous gull, an apex scavenger-predator seabird breeding in the Norwegian Arctic (Verreault et al. 2005). Perfluorooctane sulphonate levels for the glaucous gull ranged between 48 and $349 \mathrm{ng} \mathrm{g}^{-1}$ wet wt, whereas concentrations in this study ranged between 4 and $90 \mathrm{ng} \mathrm{g}^{-1}$ wet wt. Conversely, PFNA concentrations were of the same order of magnitude for both species, with glaucous gull concentrations ranging between below the detection limit $(<2.33)$ and $6.33 \mathrm{ng} \mathrm{g}^{-1}$ wet wt and ivory gull concentrations ranging between 0.15 and $5.94 \mathrm{ng} \mathrm{g}^{-1}$ wet wt. Potential detrimental effects of PFOS include a competitive interaction with thyroid hormone thyroxin (T4) for binding sites on albumin and changes in hormone homeostasis (Jones et al. 2003; Thibodeaux et al. 2003). However, predominant, it seems unlikely that PFOS alone would contribute to measurable adverse effects in the ivory gull. Nevertheless, the cocktail of accumulated PFASs 
may trigger potential additive and synergetic impacts detrimental to this species. Simultaneously in this study, PFAS concentrations in the plasma were positively correlated with the body mass of birds. This observation may be partially linked to the structural similarity between PFASs and fatty acids (Vanden Heuvel et al. 2006). However, since blood concentrations only show a snapshot of the recent exposure of the investigated organisms, the causality might be more complex. This relationship between PFAS concentrations and the body mass could have several origins. For example, individuals with higher body mass may be more efficient in catching certain prey with a higher PFAS load and/or more food in general, or alternatively, be characterized by a slower metabolism and therefore a slower distribution of PFAS to the other compartments of the body. At the same time, sex-related differences appeared between males and females, the latter displaying lower concentrations for most of the PFASs. A previous study on mallards (Anas platyrhynchos) exposed chronically to a PFOS contaminated feed demonstrated sex-dependent differences in serum PFOS concentrations where males had approximately 5 to 6 times the concentrations observed in females (Newsted et al. 2007). This study clearly demonstrated the maternal transfer of this compound to eggs. Moreover, similar to PFOS, long-chain PFAS (PFTriA, PFTeA, and PFPeDA) also showed a tendency towards high accumulation in eggs of common guillemots (Uria aalge) from the Baltic Sea (Holmström and Berger 2008). Lower PFAS concentrations in ivory gull females consequently draw attention to the potential importance of PFAS maternal transfer to the eggs at the time of their formation as a mechanism of elimination.

Polybrominated diphenyl ethers concentrations were relatively low in the ivory gull ranging between 0.67 and $7.56 \mathrm{ng} \mathrm{g}^{-1}$ wet wt in the plasma. As a comparison, sum PBDE concentrations of the glaucous gull in the Norwegian Arctic ranged from 2.49 to $54.5 \mathrm{ng} \mathrm{g}^{-1}$ wet wt in the plasma (Verreault et al. 2007). However, this previous study included 38 congeners which could imply that similar levels may be reached in the ivory gull if more congeners were taken into account. Apart from BDEs, HBB was the only other BFR that was detected in the present study. Historically, HBB was widely used in Japan as an additive to paper, plastic, and electronic goods. However, the use of this substance has been reduced by Japan (350 tons in 2001; Watanabe and Sakai 2003), and this compound is not currently produced in Europe. The low levels observed could suggest a very low background in the food web of the ivory gull and the Arctic region in general. Overall, it is difficult to draw conclusions on the potential effects of contaminants in this study. Some compounds appeared to be linked to lower body masses of the birds (e.g. HCB, PCB-118, and BDE-99), but this result may also be linked to the bird's reproductive status at the time of the sampling. 
The present study covered 4 years of observations which provided very valuable information for a number of chemical compounds. However, there were few differences between sampling years and no clear patterns were observed. For example, PFAS levels did not differ significantly between 2011 and 2013, even if this lapse of time is relatively small. Contaminant concentrations seem rather to follow episodic events of contamination in Svalbard. Nevertheless, the sampling period still remains short in this study. It appears therefore fundamental to sustain the sampling effort over several years and tissues to properly evaluate the possible contamination patterns resulting from global change in the Arctic.

\section{Relationship between trophic position, feeding habitat and contaminant bioaccumulation}

In this study, the trophic level and feeding habitats of birds, measured through $\delta^{15} \mathrm{~N}$ and $\delta^{13} \mathrm{C}$ values, were lower compared to a study using feather data from museum specimens from the Canadian Arctic and western Greenland over a 130 year period (Bond et al. 2015). Isotope values in the present study were variable, both in blood and feathers. Assuming that birds from different colonies or origins forage in food webs with similar isotopic baseline, this result indicates individual differences in trophic behaviour during the breeding (blood) and moulting (feathers) periods, respectively. The importance of polar cod to the diet of ivory gulls has been previously documented (Divoky 1976; Mehlum 1990; Mehlum and Gabrielsen 1993; Karnovsky et al. 2009). Nevertheless, individuals also feed on other fish species such as Atlantic cod (Gadus morhua) and coalfish (Pollachius virens), and amphipods (Mehlum and Gabrielsen 1993). Some ivory gulls are also known to specialize on scavenging remains of predator kills (e.g. polar bears). Ivory gulls may therefore feed on prey situated at different trophic levels (Wassmann et al. 2006). This overall variability in stable isotope values among birds can also be explained by differences in foraging strategies between breeding and nonbreeding birds. Birds were often captured at the edge of the colonies to avoid any disturbances at the nest. Consequently, some sampled individuals could have been failed breeders which may result in differences in e.g. diet, fasting status, body mass, and overall biology and ecology. Goutte et al. (2014c) demonstrated differences in foraging strategies between breeders and nonbreeding birds in an Arctic population of black-legged kittiwakes (Rissa tridactyla). Nonbreeders were potentially less constrained by energetic costs and time, and therefore displayed a higher foraging range than breeders. The same tendency was demonstrated for earlier breeders which tended to forage at farther distances than kittiwakes breeding later in the season. The same patterns could apply to the ivory gull. 
This overall variability in stable isotope values among birds is accompanied by an overlap in stable isotope values among colonies. Ivory gulls from different breeding sites demonstrated similar feeding habitats and strategies. Only birds from one colony, Sigden, displayed lower $\delta^{15} \mathrm{~N}$ and $\delta^{13} \mathrm{C}$ values in their red blood cells compared to the rest of the colonies. This result suggests a diet in this colony originating from a more offshore and lower trophic level in the month prior to the blood sampling (Hobson et al. 1994). Diet-switching experiments on birds have indeed demonstrated that the half-life of stable isotopes in red blood cells was approximately 1 month (half-life $=29.8$ days), versus $2-3$ days in the plasma fraction (half-life = 2.9 days; Hobson and Clark 1993). Nevertheless, this observation was not echoed in plasma samples where isotopic values were not significantly different between colonies. It appears rather unlikely that birds from Sigden had an entirely different trophic behaviour compared to birds from other colonies. This divergence in isotopic values for this colony could reflect a possible shift in trophic behaviour during a special event (e.g. climatic event triggering poor sea ice conditions) or a specific food source only exploited by these birds at a certain period in time. The same overlap between colonies was observed for feathers thus demonstrating similar trophic behaviour during the moulting period.

The homogeneity in feeding behaviours between different colonies is reflected by the absence of differences in contaminant concentrations. Only the Auga colony displayed lower plasma PFAS concentrations (e.g. PFOS, PFUnDA, and PFDoDA) than birds from Freemanbreen. This discrepancy could be related to several factors including the fewer number of individuals sampled in Auga compared to Freemanbreen ( $\mathrm{n}=5$ and 27, respectively). It is, however, difficult to draw exact conclusions about the origin of this difference since isotopic values in the plasma were not different between those colonies. This discrepancy may be the result of several factors including contaminant exposure of birds on their wintering and breeding grounds, the local diet, and the remobilization of contaminants from internal tissues (e.g. liver) in association with the reproductive status of individuals. Despite being amphiphilic, PFASs demonstrate bioaccumulation tendencies due to their ability to bind to proteins. Perfluorinated alkyl substances accumulated in the liver can for example be transferred to the forming egg as a protein-PFOS complex (Holmström and Berger 2008). During fasting, PFAS associated with proteins may also easily be remobilized in the blood system of birds. As specified above, birds sampled could have been failed breeders, influencing therefore their overall biology, ecology, and contaminant exposure. The rate of failed breeders may have been especially higher at Auga where predation on eggs is often high (personal observation). 
Stable isotope analysis has become a powerful tool to study dietary exposure and biomagnification of contaminants in free-ranging animal populations (Jardine et al. 2006). In this study, nitrogen values in the blood of birds were positively correlated to most of the PFASs. This result is in line with previous findings about the biomagnification potential of these compounds in the Barents Sea food web (Haukas et al. 2007). Organochlorines and BFRs are also known to biomagnify along the food chain making species at high trophic levels such as the ivory gull, more vulnerable to contaminant exposure through their diet (Hop et al. 2002; Borga et al. 2004; Braune et al. 2007). In this study, trans-nonachlor, cis-nonachlor, and BDE28 were linked to nitrogen values which denote the increase of those contaminants along the Arctic food web. Alternatively, transnonachlor was the only compound clearly correlated with carbon values in birds, demonstrating therefore that ivory gulls with the most enriched $\delta^{13} \mathrm{C}$ values probably feeding on more inshore prey have a higher tendency to bioaccumulated this persistent pollutant.

\section{Conclusion}

The most quantitatively abundant contaminants found in the ivory gull were $p, p^{\prime}$-DDE, $\Sigma$ PCB and PFOS. Overall, OC, BFR and PFAS did not suggest direct lethal risk to these compounds. Nevertheless, their potential synergetic or additive effects warrant monitoring. This study also highlighted a possible individual variability in trophic behaviour during the breeding and moulting periods, respectively. Overall, ivory gulls from different breeding sites used similar feeding habitats and strategies which were echoed by similar contaminant levels. Results for several compounds, including most of the PFASs, trans-nonachlor, cis-nonachlor, and BDE28 , are in line with previous reports about their biomagnification potential. Finally, several factors (time, colony, sex) can influence the contaminant bioaccumulation and the trophic behaviour of ivory gulls. However, this study does not allow for a full quantification of their impact due to the lack of data available on this remote species. Further research is therefore needed to better understand the contaminant pressure and foraging strategies of the ivory gull through, for example, investigation of movement patterns.

Acknowledgments. The authors wish to thank the European Commission for its financial support through a Marie Curie fellowship to M. Lucia, as well as Gael Guillou from the " "plateforme analyses isotopiques" (UMR LIENSs) for technical support during stable isotope analyses. We thank Linda Hanssen and Arntraut Götsch (NILU) for their assistance with the 
chemical analyses. We also thank Birgit Braune for her help with English. The fieldwork was supported by the Norwegian Polar Institute's centre for Ice, Climate and Ecosystems (ICE) and the SEAPOP program (seapop.no). Thanks to Vidar Bakken, Audun Igesund, Cecilie Miljeteig, Knut Olsen, Maria Gavrilo, Olivier Gilg and Odd Kindberg for help in the field.

\section{References}

ACIA (2004) Impacts of a warming Arctic: Arctic Climate Impact Assessment. Cambridge University Press.

Borgå K, Fisk AT, Hoekstra PF, Muir DCG (2004) Biological and chemical factors of importance in the bioaccumulation and trophic transfer of persistent organochlorine contaminants in Arctic marine food webs. Environ Toxicol Chem 23:2367-2385.

Bourne WRP, Bogan JA (1972) Polychlorinated biphenyls in North Atlantic seabirds. Mar Pollut Bull 3:171-175.

Braune BM, Mallory ML, Grant Gilchrist H, Letcher RJ, Drouillard KG (2007) Levels and trends of organochlorines and brominated flame retardants in Ivory Gull eggs from the Canadian Arctic, 1976 to 2004. Sci Total Environ 378:403-417.

Bustnes JO, Bakken V, Erikstad KE, Mehlum F, Skaare JU (2001) Patterns of incubation and nest-site attentiveness in relation to organochlorine (PCB) contamination in glaucous gulls. J Appl Ecol 38:791-801.

Butt CM, Berger U, Bossi R, Tomy GT (2010) Levels and trends of poly- and perfluorinated compounds in the arctic environment. Sci Total Environ 408:2936-2965.

Cherel Y, Robin JP, Le Maho Y (1988) Physiology and biochemistry of long-term fasting in birds. Can J Zool 66:159-166.

Covaci A, Harrad S, Abdallah MAE, Ali N, Law RJ, Herzke D, de Wit CA (2011) Novel brominated flame retardants: A review of their analysis, environmental fate and behavior. Environ Int 37:532-556.

Dawson A (2000) Mechanisms of endocrine disruption with particular reference to occurrence in avian wildlife: A review. Ecotoxicology 9:59-69.

de Wit CA, Fisk A, Hobbs K, Muir D, Gabrielsen G, Kallenborn R, Krahn M, Norstrom R, Skaare J (2004) AMAP Assessment 2002: Persistent Organic Pollutants in the Arctic. Arctic Monitoring and Assessment Program, Oslo, Norway.

de Wit CA, Herzke D, Vorkamp K (2010) Brominated flame retardants in the Arctic environment-Trends and new candidates. Sci Total Environ 408:2885-2918. 
Divoky GJ (1976) The pelagic feeding habits of ivory and Ross' gulls. Condor 78:85-90.

Gabrielsen GW, Skaare JU, Polder A, Bakken V (1995) Chlorinated hydrocarbons in glaucous gulls (Larus hyperboreus) in the southern part of Svalbard. Sci Total Environ 160-161:337346.

Giesy JP, Kannan K (2001) Global distribution of perfluorooctane sulfonate in wildlife. Environ Sci Technol 35:1339-1342.

Gilg O, Strøm H, Aebischer A, Gavrilo MV, Volkov AE, Miljeteig C, Sabard B (2010) Postbreeding movements of northeast Atlantic ivory gull Pagophila eburnea populations. J Avian Biol 41:532-542.

Goutte A, Angelier F, Bech C, Clément-Chastel C, Dell'Omo G, Gabrielsen GW, Lendvai AZ, Børge M, Noreen E, Pinaud D, Tartu S, Chastel O (2014c) Annual variation in the timing of breeding, pre-breeding foraging areas and corticosterone levels in an Arctic population of black-legged kittiwakes. Mar Ecol Prog Ser 496:233-247.

Goutte A, Barbraud C, Meillère A, Carravieri A, Bustamante P, Labadie P, Budzinski H, Delord K, Cherel Y, Weimeskirch H, Chastel O (2014a) Demographic consequences of heavy metals and persistent organic pollutants in a vulnerable long-lived bird, the wandering albatross. Proc R Soc B 281:20133313.

Goutte A, Bustamante P, Barbraud C, Delord K, Weimeskirch H, Chastel O (2014b) Demographic responses to mercury exposure in two closely-related Antarctic top predators. Ecology 95:1075-1086.

Grant Gilchrist H, Mallory ML (2005) Declines in abundance and distribution of the ivory gull (Pagophila eburnea) in Arctic Canada. Biol Cons 121:303-309.

Haukås M, Berger U, Hop H, Gulliksen B, Gabrielsen GW (2007) Bioaccumulation of per- and polyfluorinated alkyl substances (PFAS) in selected species from the Barents Sea food web. Environ Pollut 148:360-71.

Herzke D, Nygård T, Berger U, Huber S, Røv N (2009) Perfluorinated and other persistent halogenated organic compounds in European shag (Phalacrocorax aristotelis) and common eider (Somateria mollissima) from Norway: a suburban to remote pollutant gradient. Sci Total Environ 408:340-348.

Hobson KA, Clark RG (1993) Turnover of $\mathrm{d}^{13} \mathrm{C}$ and plasma fractionations in blood: implications for non-destructive sampling in avian dietary studies. Auk 110:638-641.

Hobson KA, Fisk A, Karnovsky N, Holst M, Gagnon JM, Fortier M (2002) A stable isotope $\left(\delta^{13} \mathrm{C}, \delta^{15} \mathrm{~N}\right)$ model for the North Water food web: implications for evaluating trophodynamics and the flow of energy and contaminants. Deep-Sea Res II 49:5131-5150. 
Hoegh-Guldberg O, Bruno JF (2010) The impact of climate change on the world's marine ecosystems. Science 328:1523-1528.

Hop H, Borgå K, Gabrielson GW, Kleivane L, Skaare JU (2002) Food web magnification of persistent organic pollutants in poikilotherms and homeotherms from the Barents Sea. Environ Sci Technol 36:2589-2597.

Howell SNG (2001) Molt of the Ivory Gull. Waterbirds 24:438-442.

Jardine TD, Kidd KA, Fisk AT (2006) Applications, considerations, and sources of uncertainty when using stable isotope analysis in ecotoxicology. Environ Sci Technol 40:7501-7511.

Jones PD, Hu W, de Coen W, Newsted JL, Giesy JP (2003) Binding of perfluorinated fatty acids to serum proteins. Environ Toxicol Chem 22:2639-2649.

Karnovsky NJ, Hobson KA, Brown ZW, Hunt GL Jr (2009) Distribution and diet of ivory gulls (Pagophila eburnea) in the North Water Polynya. Arctic 62:65-74.

Keith JO, Mitchell CA (1993) Effects of DDE and food stress on reproduction and body condition of ringed turtle doves. Arch Environ Contam Toxicol 25:192-203.

Le Maho Y, Vu Van Kha H, Koubi H, Dewasmes G, Girard J, Ferre P, Cagnard M (1981) Body composition, energy expenditure, and plasma metabolites in long-term fasting geese. Am $\mathbf{J}$ Physiol Endocrinol Metab 241:342-354.

Lucia M, Verboven N, Strøm H, Miljeteig C, Gavrilo MV, Braune BM, Boertmann D, Gabrielsen GW (2015) Circumpolar contamination in eggs of the high-arctic ivory gull Pagophila eburnea. Environ Toxicol Chem doi:10.1002/etc.2935.

Macdonald RW, Harner T, Fyfe J (2005) Recent climate change in the Arctic and its impact on contaminant pathways and interpretation of temporal trend data. Sci Total Environ 342:586.

Martin JW, Smithwick MM, Braune BM, Hoekstra PF, Muir DCG, Mabury SA (2004) Identification of long-chain perfluorinated acids in biota from the Canadian Arctic. Environ Sci Technol 38:373-380.

McArthur MLB, Fox GA, Peakall DB, Philogéne BJR (1983) Ecological significance of behavioral and hormonal abnormalities in breeding ring doves fed an organochlorine chemical mixture. Arch Environ Contam Toxicol 12:343-353.

Mehlum F (1990) Seabird distribution in the northern Barents Sea marginal ice-zone during late summer. Polar Res 8:61-65.

Mehlum F, Gabrielsen GW (1993) The diet of High-Arctic seabirds in coastal and ice-covered, pelagic areas near the Svalbard archipelago. Polar Res 12:1-20. 
Miljeteig C, Strøm H, Gavrilo MV, Volkov A, Jenssen BM, Gabrielsen GW (2009) High levels of contaminants in ivory gull Pagophila eburnea eggs from the Russian and Norwegian Arctic. Environ Sci Technol 43:5521-5528.

Peakall DB (1985) Behavioral responses of birds to pesticides and other contaminants. Residue Rev 96:45-77.

Pilo B, George JC (1983) Diurnal and seasonal variation in liver glycogen and fat in relation to metabolic status of liver and m. pectoralis in the migratory starling, Sturnus roseus, wintering in India. Comp Biochem Physiol A Comp Physiol 74:601-604.

Powley CR, George SW, Ryan TW, Buck RC (2005) Matrix effect-free analytical methods for determination of perfluorinated carboxylic acids in environmental matrixes. Anal Chem 77:6353-6358.

Quaintenne G, van Gils JA, Bocher P, Dekinga A, Piersma T (2010) Diet selection in a molluscivore shorebird across Western Europe: does it show short- or long-term intake ratemaximization? J Anim Ecol 79:53-62.

Renner R (2000) What fate for bromimated fire retardants? Environ Sci Technol 34:222A226A.

Serreze MC, Holland MM, Stroeve J (2007) Perspectives on the Arctic's shrinking sea-ice cover. Science 315:1533-1536.

Thibodeaux JR, Hanson RG, Rogers JM, Grey BE, Barbee BD, Richards JH, Butenhoff JL, Stevenson LA, Lau C (2003) Exposure to perfluorooctane sulfonate during pregnancy in rat and mouse. I: Maternal and prenatal evaluations. J Toxicol Sci 74:369-381.

Tomy GT, Budakowsky W, Halldorson T, Helm PA, Stern GA, Friesen K, Pepper K, Tittlemier SA, Fisk AT (2004) Fluorinated organic compounds in an eastern Arctic marine foood web. Environ Sci Technol 38:6475-6481.

Vanden Heuvel JP, Thompson JT, Frame SR, Gillies PJ (2006) Differential activation of nuclear receptors by perfluorinated fatty acid analogs and natural fatty acids: A comparison of human, mouse, and rat peroxisome proliferator-activated receptor- $\alpha,-\beta$, and - $\gamma$, liver $X$ receptor- $\beta$, and retinoid X receptor- $\alpha$. Toxicol Sci 92:476-489.

Verreault J, Gebbink WA, Gauthier LT, Gabrielsen GW, Letcher RJ (2007) Brominated flame retardants in glaucous gulls form the Norwegian Arctic: More than just an issue of polybrominated diphenyl ethers. Environ Sci Technol 41:4925-4931.

Verreault J, Houde M, Gabrielsen GW, Berger U, Haukås M, Letcher RJ, Muir DCG (2005) Perfluorinated alkyl substances in plasma, liver, brain, and eggs of glaucous gulls (Larus hyperboreus) from the Norwegian Arctic. Environ Sci Technol 39:7439-7445. 
Verreault J, Skaare JU, Jenssen BM, Gabrielsen GW (2004) Effects of organochlorine contaminants on thyroid hormone levels in Arctic breeding glaucous gulls, Larus hyperboreus. Environ Health Perspect 112:532-537.

Watanabe I, Sakai S (2003) Environmental release and behavior of brominated flame retardants. Environ Int 29:665-682.

Weber LM, Haig SM (1997) Shorebird diet and size selection of Nereid polychaetes in South Carolina coastal diked wetlands. J Field Ornithol 68:358-366. 


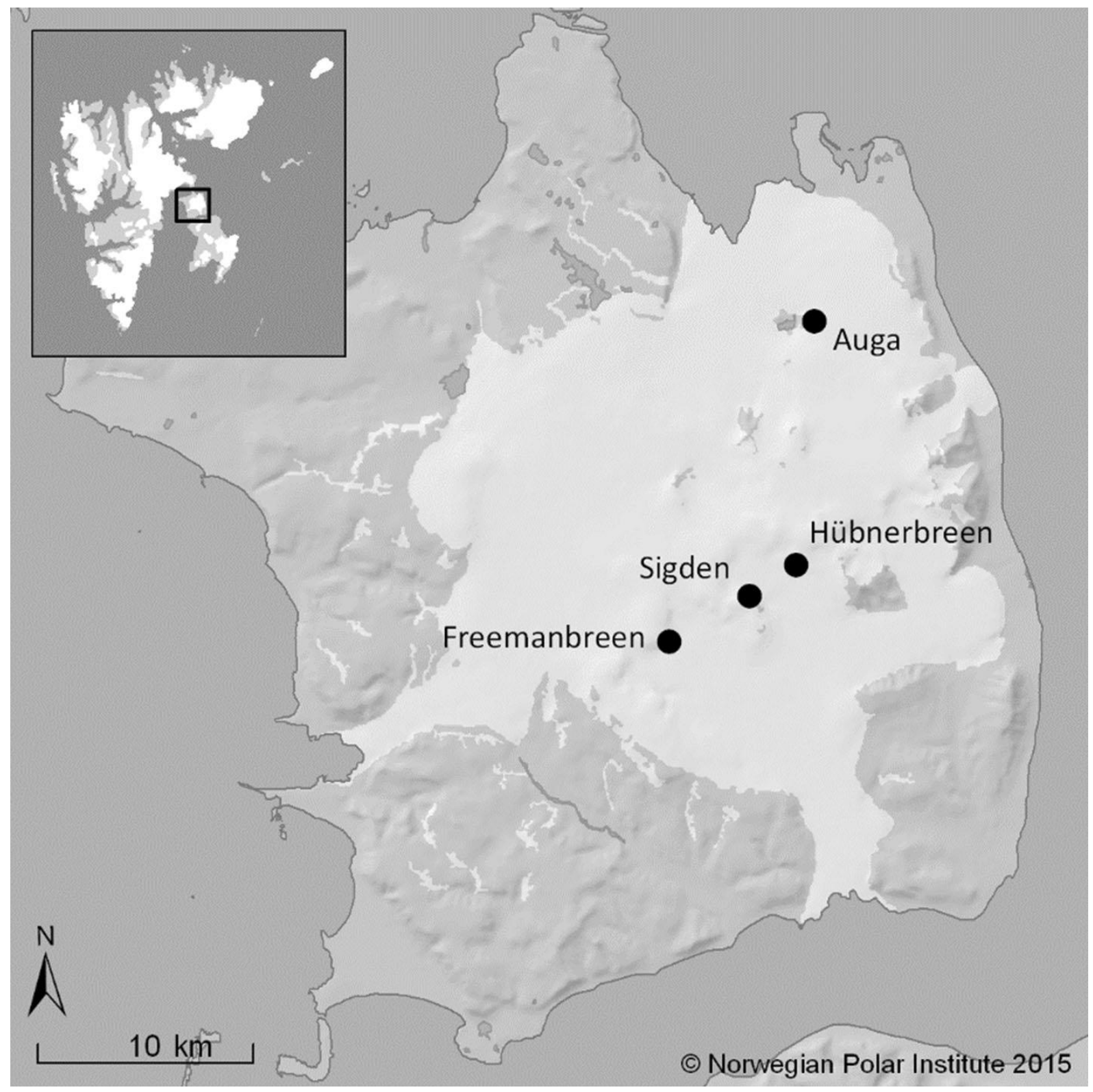

Figure 1. Locations of the four ivory gull (Pagophila eburnea) colonies sampled on Barentsøya $\left(78^{\circ} 25^{\prime} \mathrm{N}, 21^{\circ} 27^{\prime} \mathrm{E}\right)$, Svalbard, Norway. 

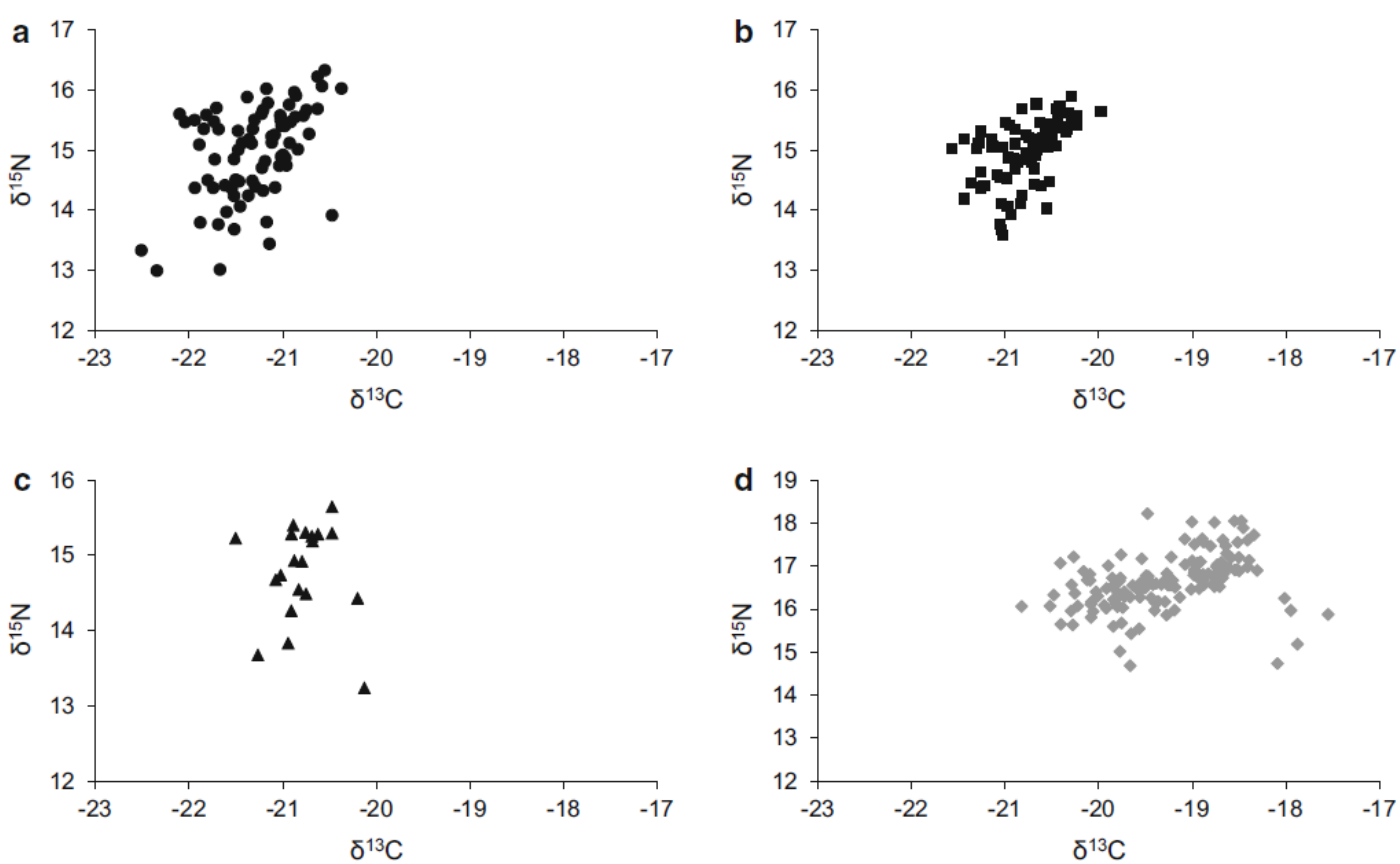

Figure 2. Carbon $\left(\delta^{13} \mathrm{C}\right)$ and nitrogen $\left(\delta^{15} \mathrm{~N}\right)$ isotopic values (mean $\left.\% \pm \mathrm{SD}\right)$ in a) plasma $(\mathrm{n}=$ $76)$, b) red blood cells $(n=76)$, c) whole blood $(n=20)$ and $\mathbf{d})$ ventral feathers $(n=139)$ of ivory gulls from Svalbard. 


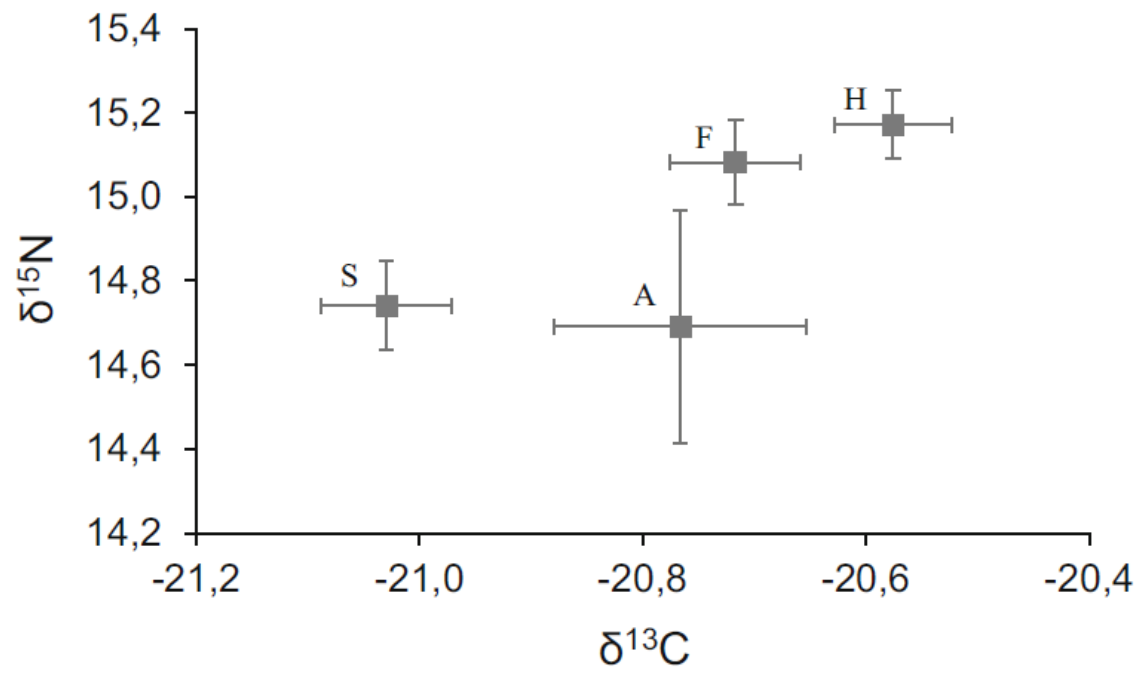

Figure 3. Carbon $\left(\delta^{13} \mathrm{C}\right)$ and nitrogen $\left(\delta^{15} \mathrm{~N}\right)$ isotopic values (mean $\left.\% \pm \mathrm{SD}\right)$ in red blood cells of ivory gulls sampled from four colonies on Barentsøya, Svalbard: Hübnerbreen $(H ; n=19)$, Freemanbreen ( $F ; n=27)$, Auga $(A ; n=5)$ and Sigden $(S ; n=25)$. 

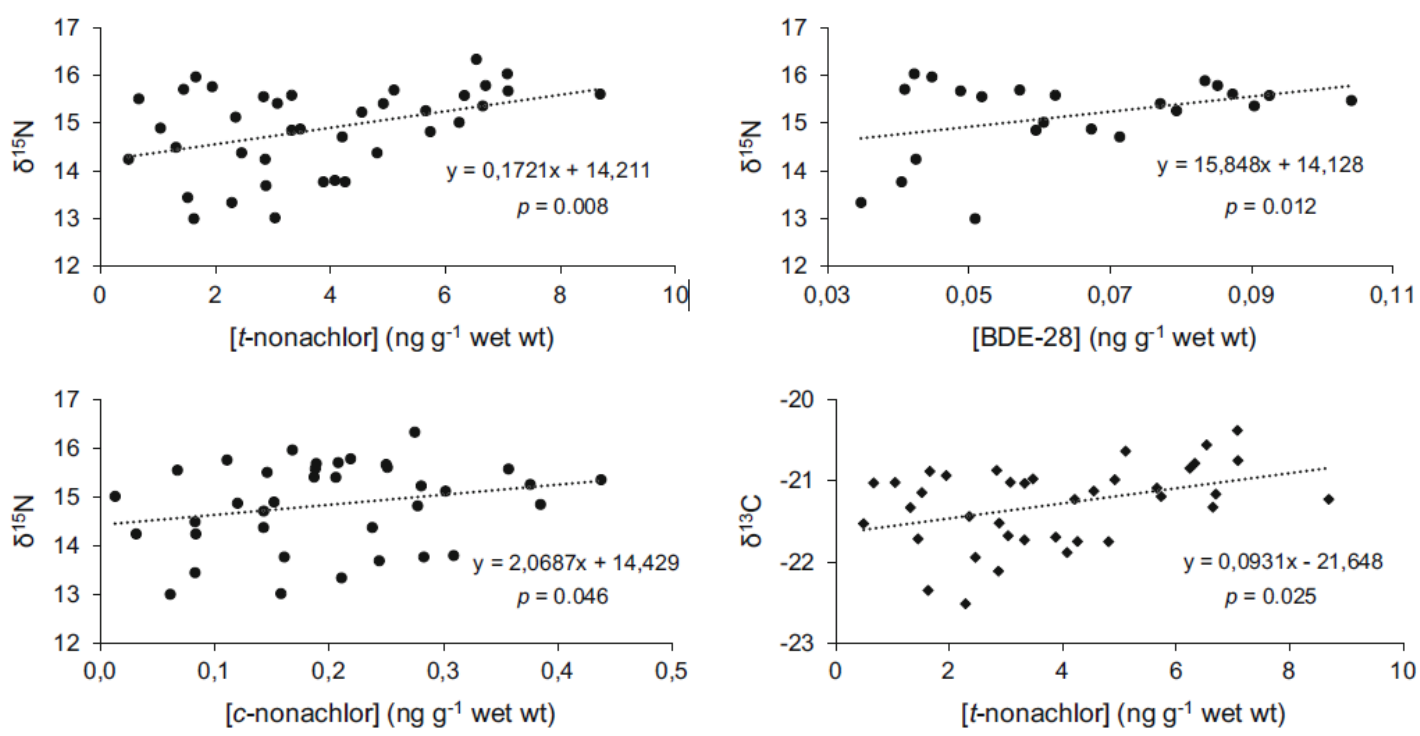

Figure 4. $\delta^{15} \mathrm{~N}$ values versus trans-nonachlor, BDE-28 and cis-nonachlor concentrations (ng g ${ }^{1}$ wet wt) and $\delta^{13} \mathrm{C}$ values versus trans-nonachlor concentrations (ng $\mathrm{g}^{-1}$ wet wt) in plasma of ivory gulls. Equations of the trend curves were indicated for each graphs. 
Table 1. Mean concentrations ( $\mathrm{ng} \mathrm{g}^{-1}$ wet wt \pm standard deviation) and ranges (min-max) of perfluorinated alkyl substances in the plasma in $2013(\mathrm{n}=38)$ and $2014(\mathrm{n}=21)$, and the whole blood in $2011(\mathrm{n}=4), 2012(\mathrm{n}=5)$ and $2013(\mathrm{n}=1)$ of ivory gulls (Pagophila eburnea) from Svalbard.

\begin{tabular}{|c|c|c|c|c|c|c|c|c|c|}
\hline & \multicolumn{4}{|l|}{ Plasma } & \multicolumn{5}{|l|}{ Whole blood } \\
\hline & \multicolumn{2}{|l|}{2013} & \multicolumn{2}{|l|}{2014} & \multicolumn{2}{|l|}{2011} & \multicolumn{2}{|l|}{2012} & \multirow{2}{*}{$\begin{array}{l}2013 \\
\text { Mean }\end{array}$} \\
\hline & Mean & Min-max & Mean & Min-max & Mean & Min-max & Mean & Min-max & \\
\hline PFOS & $31.04 \pm 3.14$ & $4.37-89.81$ & $28.34 \pm 3.04$ & $4.37-59.18$ & $8.88 \pm 0.47$ & $5.92-10.86$ & $55.16 \pm 7.43$ & $23.34-137.89$ & 6.88 \\
\hline PFNA & $1.64 \pm 0.18$ & $0.15-5.94$ & $1.59 \pm 0.20$ & $0.46-4.50$ & $1.03 \pm 0.07$ & $0.66-1.39$ & $2.89 \pm 0.60$ & $0.69-9.69$ & 0.48 \\
\hline PFHxS & $0.10 \pm 0.02$ & $<0.05-0.46$ & $0.10 \pm 0.02$ & $<0.05-0.39$ & $0.08 \pm 0.01$ & $<0.05-0.13$ & $0.13 \pm 0.02$ & $<0.05-0.36$ & $<0.05$ \\
\hline PFDA & $2.39 \pm 0.18$ & $0.10-4.83$ & $2.44 \pm 0.24$ & $0.84-4.78$ & $0.91 \pm 0.05$ & $0.64-1.19$ & $3.31 \pm 0.30$ & $1.62-6.41$ & 0.69 \\
\hline PFUnDA & $13.73 \pm 1.06$ & $2.10-29.35$ & $11.33 \pm 1.02$ & $4.44-21.35$ & $4.72 \pm 0.26$ & $3.06-5.79$ & $18.80 \pm 0.88$ & $10.73-25.39$ & 5.10 \\
\hline PFDoDA & $2.49 \pm 0.19$ & $<0.05-5.35$ & $2.14 \pm 0.18$ & $0.80-3.79$ & $0.92 \pm 0.05$ & $0.74-1.23$ & $3.77 \pm 0.14$ & $2.63-4.98$ & 0.85 \\
\hline PFTriA & $7.09 \pm 0.51$ & $2.23-16.11$ & $7.24 \pm 0.62$ & $3.32-14.72$ & $5.28 \pm 0.30$ & $3.23-6.57$ & $11.06 \pm 0.29$ & $9.49-13.72$ & 3.42 \\
\hline PFTeA & $0.80 \pm 0.07$ & $0.20-2.04$ & $0.68 \pm 0.08$ & $<0.05-1.29$ & $0.62 \pm 0.07$ & $0.15-0.91$ & $1.36 \pm 0.05$ & $1.00-1.81$ & 0.22 \\
\hline
\end{tabular}

PFOS perfluorooctane sulphonate, PFNA perfluorononanoate, $P F H x S$ perfluorohexane sulphonate, $P F D A$ perfluoro-n-decanoic acid, $P F U n D A$ perfluoroundecanoic acid, PFDoDA perfluorododecanoic acid, PFTriA perfluorotridecanoic acid, PFTeA perfluorotetradecanoic acid 
Table 2. Mean concentrations ( $\mathrm{ng} \mathrm{g}^{-1}$ wet wt \pm standard deviation) and ranges (min-max) of organochlorines and brominated flame retardants in the plasma in $2013(\mathrm{n}=30)$ and $2014(\mathrm{n}=$ $9)$, and the whole blood in $2011(n=4)$ and $2012(n=2)$ of ivory gulls from Svalbard

\begin{tabular}{|c|c|c|c|c|c|c|c|c|}
\hline & \multicolumn{4}{|l|}{ Plasma } & \multicolumn{4}{|l|}{ Whole blood } \\
\hline & \multicolumn{2}{|l|}{2013} & \multicolumn{2}{|l|}{2014} & \multicolumn{2}{|l|}{2011} & \multicolumn{2}{|l|}{2012} \\
\hline & Mean & Min-max & Mean & Min-max & Mean & Min-max & Mean & Min-max \\
\hline Lipid \% & $1.14 \pm 0.04$ & $0.74-1.57$ & $1.42 \pm 0.22$ & $0.71-2.82$ & $0.12 \pm 0.02$ & $0.08-0.16$ & $0.16 \pm 0.04$ & $0.12-0.20$ \\
\hline $\mathrm{HCB}$ & $7.94 \pm 0.56$ & $2.22-16.40$ & $13.12 \pm 2.99$ & $6.16-32.46$ & $4.17 \pm 0.76$ & $2.01-5.39$ & $7.19 \pm 0.93$ & $6.26-8.12$ \\
\hline oxychlordane & $25.8 \pm 2.90$ & $6.75-74.22$ & $36.1 \pm 10.94$ & $9.93-110$ & $6.77 \pm 2.24$ & $1.89-12.5$ & $14.2 \pm 1.88$ & $12.3-16.1$ \\
\hline$t$-nonachlor & $4.43 \pm 0.70$ & $0.49-22.7$ & $5.25 \pm 1.50$ & $1.32-16.5$ & $4.22 \pm 2.23$ & $0.98-10.6$ & $2.20 \pm 0.40$ & $1.80-2.59$ \\
\hline$c$-nonachlor & $0.28 \pm 0.06$ & $0.03-1.90$ & $0.33 \pm 0.12$ & $\mathrm{nd}-1.22$ & $0.01 \pm 0.005$ & $0.04-0.06$ & $0.01 \pm 0.003$ & nd -0.01 \\
\hline $\operatorname{mirex}$ & $10.4 \pm 1.07$ & $3.40-29.3$ & $8.53 \pm 1.70$ & nd-19.2 & $1.40 \pm 0.83$ & $0.46-3.88$ & $3.11 \pm 0.16$ & $2.94-3.27$ \\
\hline$p, p^{\prime}-\mathrm{DDE}$ & $303 \pm 38.9$ & $57.8-1058$ & $252 \pm 55.9$ & $65.1-626$ & $66.0 \pm 29.6$ & $27.2-153$ & $122 \pm 24.0$ & $98.4-147$ \\
\hline PCB-28 & $0.29 \pm 0.02$ & $0.08-0.62$ & $0.25 \pm 0.06$ & $0.10-0.54$ & $0.12 \pm 0.03$ & $0.06-0.18$ & $0.26 \pm 0.06$ & $0.20-0.32$ \\
\hline PCB-99 & $33.6 \pm 3.98$ & $9.10-98.1$ & $32.9 \pm 7.75$ & $9.10-84.5$ & $8.26 \pm 3.32$ & $2.21-17.7$ & $19.0 \pm 3.35$ & $15.6-22.3$ \\
\hline PCB-101 & $0.41 \pm 0.05$ & nd-1.16 & $0.42 \pm 0.09$ & nd-0.98 & $0.18 \pm 0.06$ & $0.07-0.31$ & $0.26 \pm 0.07$ & $0.19-0.32$ \\
\hline PCB-105 & $6.02 \pm 0.69$ & $1.12-16.0$ & $6.08 \pm 1.58$ & $1.79-16.8$ & $1.52 \pm 0.50$ & $0.61-2.74$ & $3.81 \pm 0.94$ & $2.87-4.75$ \\
\hline PCB-1 18 & $23.7 \pm 2.53$ & $5.99-63.9$ & $27.3 \pm 7.02$ & $7.47-78.2$ & $5.90 \pm 2.42$ & $1.92-12.7$ & $16.3 \pm 3.63$ & $12.6-19.9$ \\
\hline PCB-138 & $133 \pm 15.4$ & $33.0-386$ & $124 \pm 26.3$ & $36.5-311$ & $26.0 \pm 13.6$ & $8.38-66.3$ & $55.9 \pm 5.23$ & $50.7-61.1$ \\
\hline PCB-153 & $202 \pm 23.5$ & $52.3-656$ & $169 \pm 32.1$ & $48.1-394$ & $34.7 \pm 16.6$ & $11.2-83.4$ & $77.1 \pm 8.9$ & $68.3-86.0$ \\
\hline PCB-180 & $93.4 \pm 10.4$ & $22.8-282$ & $74.8 \pm 12.9$ & $26.7-163$ & $13.6 \pm 7.71$ & $4.36-36.6$ & $28.8 \pm 0.42$ & $28.4-29.2$ \\
\hline PCB-183 & $15.4 \pm 1.71$ & $3.78-46.2$ & $13.5 \pm 2.34$ & $4.70-29.6$ & $2.56 \pm 1.64$ & $0.83-7.47$ & $4.92 \pm 0.01$ & $4.91-4.92$ \\
\hline PCB-187 & $9.89 \pm 1.20$ & $1.47-30.1$ & $10.5 \pm 2.33$ & $3.11-25.3$ & $3.12 \pm 1.52$ & $0.95-7.54$ & $4.56 \pm 0.87$ & $3.69-5.42$ \\
\hline PCB-194 & $10.4 \pm 1.04$ & $2.84-25.8$ & $6.56 \pm 0.87$ & $2.90-11.2$ & $1.40 \pm 0.81$ & $0.39-3.81$ & $2.79 \pm 0.28$ & $3.07-2.51$ \\
\hline$\sum_{11} \mathrm{PCB}^{\mathrm{a}}$ & $527 \pm 59.4$ & $134-1597$ & $465 \pm 91.4$ & $141-1115$ & $97.4 \pm 47.6$ & $31.1-239$ & $213 \pm 22.3$ & $191-236$ \\
\hline BDE-28 & $0.04 \pm 0.01$ & nd -0.10 & $0.03 \pm 0.01$ & nd- -0.08 & nd & nd & nd & nd \\
\hline BDE-47 & $1.63 \pm 0.20$ & $0.33-4.87$ & $1.60 \pm 0.37$ & $0.70-4.06$ & $0.61 \pm 0.17$ & $0.27-0.98$ & $0.92 \pm 0.29$ & $0.63-1.21$ \\
\hline BDE-99 & $0.32 \pm 0.04$ & nd-1.01 & $0.33 \pm 0.12$ & nd- 1.00 & $0.10 \pm 0.05$ & nd -0.23 & $0.23 \pm 0.11$ & $0.12-0.35$ \\
\hline BDE-100 & $0.13 \pm 0.02$ & nd -0.53 & $0.07 \pm 0.05$ & nd- -0.49 & $0.07 \pm 0.03$ & nd -0.14 & $0.08 \pm 0.001$ & $0.076-0.077$ \\
\hline BDE-153 & $0.34 \pm 0.04$ & nd -0.94 & $0.25 \pm 0.05$ & $\mathrm{nd}-0.55$ & $0.06 \pm 0.04$ & nd -0.164 & $0.07 \pm 0.05$ & nd -0.115 \\
\hline BDE-154 & $0.05 \pm 0.01$ & nd -0.28 & $0.03 \pm 0.01$ & $\mathrm{nd}-0.14$ & $0.02 \pm 0.02$ & nd -0.09 & nd & nd \\
\hline BDE-183 & $0.28 \pm 0.10$ & nd-2.70 & nd & nd & $0.27 \pm 0.19$ & nd -0.83 & nd & nd -0.34 \\
\hline$\sum \mathrm{PBDE}^{\mathrm{b}}$ & $2.79 \pm 0.29$ & $0.67-7.56$ & $2.35 \pm 0.55$ & $0.96-6.09$ & $1.14 \pm 0.39$ & $0.38-2.04$ & $1.29 \pm 0.45$ & $0.84-1.75$ \\
\hline HBB & $0.005 \pm 0.001$ & nd -0.032 & $0.003 \pm 0.001$ & nd -0.007 & $0.01 \pm 0.005$ & nd -0.022 & $0.004 \pm 0.001$ & $0.003-0.005$ \\
\hline
\end{tabular}

$n d$ below detection limit, $H C B$ hexachlorobenzene, $D D E$ dichlorodiphenyldichloroethylene, $P C B$ polychlorobiphenyl, $B D E$ brominated diphenyl ether, $H B B$ hexabromobenzene

${ }^{a}$ Sum of PCB-28, $-99,-101,-105,-118,-138,-153,-180,-183,-187$, and -194

b Sum of BDE in 2011 include BDE-47, -99, -100,-153,-154, and -183; Sum of BDE in 2012 include BDE-47, -99, -100, and -153; Sum of BDE in 2013 include BDE-28, $-47,-99,-100,-153,-154$, and -183; Sum of BDE in 2014 include BDE-28, -47, -99, -100, -153, and -154 